\title{
CALCULATION OF MECHANICAL AND FOUNDRY CHARACTERISTICS OF AI-Si ALLOYS USING REGRESSION ANALYSIS
}

\author{
Peter BLAŠKO, Jozef PETRÍK, Pavol PALFY, Alena PRIBULOVÁ, Peter FUTÁŠ, \\ Andrea BLAŠKOVÁ
}

TUKE-Technical University of Košice, Košice, Slovakia, EU, peter.blasko@tuke.sk

https://doi.org/10.37904/metal.2021.4255

\begin{abstract}
$\mathrm{Al}-\mathrm{Si}$ alloys alloyed with $\mathrm{Mn}$ and $\mathrm{Mg}$ are widely used in industry, especially as cast alloys. The presence of $\mathrm{Mg}$ allows subsequent heat treatment, which will improve mechanical properties. Al-Si alloys generally contain Fe; its content between 0.3 and $0.5 \mathrm{wt} \%$ increases strength and fluidity. But the content higher than $1 \mathrm{wt} \%$ causes the formation long, hard, and brittle needles of $\beta$ - phase (FeSiAl 5 ) which act as notches. Mn improves strength and mechanical properties at high temperature. Excessive Fe segregate with $\mathrm{Mn}$ in coarse "chinese script" particles $(\mathrm{Fe}, \mathrm{Mn})_{3} \mathrm{Si}_{2} \mathrm{Al}_{15}$ which are less harmful than $\beta$ - phase. Alloys containing 3.8-11.20 wt\% $\mathrm{Si}, 0.12-1.76$ wt $\% \mathrm{Fe}, 0-2.25 \mathrm{wt} \% \mathrm{Mn}$ and 0-0.73 wt\% $\mathrm{Mg}$, modified with $0.02 \mathrm{wt} \% \mathrm{Sr}$ were analysed. The samples were cast in the form of a "harp" for calculating the fluidity by the vertical method and in samples for tensile tests ultimate tensile strength $\left(R_{m}\right)$, total elongation $\left(A_{5}\right)$, the reduction of the area (contraction $Z$ ), and hardness $H V 10$ were determined. In addition, the microstructure was evaluated. From these sources, the equations that define the relationship between the composition of the alloy and its properties were determined by linear regression analysis. There is a strong correlation $\left(r^{2}=0.73-0.81\right)$ between the properties calculated with obtained equations and the actual values. The content of $\mathrm{Mn}(0.3 \mathrm{wt} \%)$ and $\mathrm{Mg}(0.25 \mathrm{wt} \%)$ was determined by optimization using DoE (design of experiments), which will ensure optimal values of the analysed properties.
\end{abstract}

Keywords: Metallurgy, Al-Si alloys, composition, properties, regression

\section{INTRODUCTION}

In connection with the tendency to reduce the environmental burden and the consumption of primary sources of raw materials and energy, there is ever-increasing pressure to use secondary sources. Among the nonferrous metals, aluminum and its alloys are getting to the centre of attention. The production and refining of secondary aluminum require only about $5 \%$ of the energy needed to produce primary aluminum. Its recycling is complicated by the fact that in technical practice it is used in the form of alloys, the processing of which brings many specific problems. Alloys for casting usually have higher alloying element content (up to $20 \mathrm{wt} \%$ ) than alloys intended for forming (up to 10\%). Therefore, this scrap is recycled only into foundry alloys, whereas removing the most of alloying elements from molten aluminum would be impractical [1, p. 84].

The paper deals namely with Al-Si casting alloys, i.e. silumin. In the production of aluminum alloys of waste material, there may be a problem with the homogeneity of the batch and with the uncertainty of its chemical composition, which usually does not meet the standard. Therefore we must assess the possibility of correction by diluting the melt. However, the lower the concentration, the more difficult the dilution [2, p. 17].If the customer does not insist on a specific standardized composition and only cares about the foundry and/or mechanical properties, the manufacturer can use the regression equations presented in this contribution to calculate the fluidity, hardness, yield strength, ductility, and contraction of the casting. The equations must be applied for concentrations of $\mathrm{Si}, \mathrm{Fe}, \mathrm{Mn}$ and $\mathrm{Mg}$ mentioned further. The cooling rate of the casting should be 
about $20^{\circ} \mathrm{C} . \mathrm{s}^{-1}$. It is assumed that the alloy will be modified. Using $\mathrm{Sr}$ as a modifier, its final content of 0.02 wt $\%$ is sufficient for complete globularization of eutectic silicon.

\section{ELEMENTS INFLUENCING THE PROPERTIES OF AI-Si}

Aluminum casting alloys have several advantages over other foundry alloys. These have, in particular, good fluidity, low melting point and solidification interval, and good corrosion resistance [3, p. 94]. Binary Al-Si alloys are intended for the production of shaped castings by casting in sand, metal moulds, or for die-casting. The maximum tensile strength is usually around $250 \mathrm{MPa}$.

Achieving a higher foundry quality of silumin together with uniform properties is possible by using other alloying elements. The additives in Al-Si alloys for casting include in particular:

Mg- is added in the amount of 0.3 to $0.75 \mathrm{wt} \%$. It allows enhancing the strength properties by hardening with the help of the $\mathrm{Mg}_{2} \mathrm{Si}$ phase. Magnesium reduces ductility and fluidity but does not reduce corrosion resistance $[4,5]$.

$\mathrm{Mn}$ - increases strength, corrosion, and fatigue resistance, reduces porosity. Under its effect, iron precipitates take the form of a skeleton shape $\mathrm{Al}_{15}(\mathrm{MnFe})_{3} \mathrm{Si}_{2}$ particles (Chinese script). The manganese content in Al-Si alloys should be equal to about $1 / 2$ iron of content.

$\mathrm{Fe}-\quad$ is a common impurity in aluminum alloys. Depending on the quality of the raw materials, the primary aluminum contains between 0.03 and $0.15 \mathrm{wt} \% \mathrm{Fe}$. At present, there is no known reliable and economic method removal of iron from aluminum alloys. Gravitational methods are effective, but economically disadvantageous [6]. Iron harms strength, plastic properties, corrosion resistance, and fluidity. At contents higher than 0.3 to $0.5 \mathrm{wt} \%$ it forms undesired hard and brittle intermetallic phases. Particularly unpleasant are the $\beta$-phase needles ( $\mathrm{Al}_{5} \mathrm{FeSi}$ ), which, depending on the composition and cooling rate of the casting, begin to form at the content of $0.7-1.0 \mathrm{wt} \% \mathrm{Fe}$. In extreme cases, their length exceeds 1000 $\mu \mathrm{m}$. As they are hard and brittle, they act like notches and intensely reduce not only the mechanical properties of the castings (strength, ductility) but also fluidity. They increase the creep resistance at elevated temperatures and the resulting hardness of the castings, which may or may not be desirable $[4,7]$.

\section{SAMPLE PREPARATION AND REGRESSION ANALYSIS}

185 samples with chemical composition in the range of 3.80-11.20 wt\% Si, 0.12-1.76 wt\% Fe, 0-2.25 wt\% $\mathrm{Mn}$, and $0-0.73 \mathrm{wt} \% \mathrm{Mg}$, and $\mathrm{Sr}$ as $0.02 \pm 0.002 \mathrm{wt} \%$ were used for analysis. The melt was cast at $760{ }^{\circ} \mathrm{C}$ into a chill mould for tensile test samples (3-5) and a chill mould ("harph" or "lyre", details in [8]) for the vertical fluidity test. The tensile test was performed on a $200 \mathrm{kN}$ Zwick-Extensometer according to ISO 6892-1 [9]. The ultimate tensile strength $R_{m}(\mathrm{MPa})$, the total elongation $A_{5}(\%)$, and the reduction of the area, contraction $Z$ (\%) were evaluated. The hardness of the sample head part was measured by the Vickers method HV10 according to ISO 6507-1 [10] with five indentations. The tester HPO 250 met the requirements of the standard ISO 65072 [11] during calibration.

The metallographic samples were ground with water-cooled sandpapers in sequence $220,240 \ldots 3000$ ANSI/CAMI grit, polished with an aqueous suspension of $\mathrm{Al}_{2} \mathrm{O}_{3}$ to mirror finish and etched with $0.7 \% \mathrm{HF}$. Eutectic silicon is precipitated in the form of globules with a diameter of up to $4 \mu \mathrm{m}$, partly in the form of fine lamellae with a length of about $10 \mu \mathrm{m}$. The interparticle spacing of these $\lambda_{\beta}$ particles is $2.5 \mu \mathrm{m}$ on average. At higher manganese content $(>0.5 \mathrm{wt} \%)$ in eutectic occur skeleton shapes "Chinese script" $(\mathrm{FeMn})_{3} \mathrm{Si}_{2} \mathrm{Al}_{15}$ with a maximum diameter of $80 \mu \mathrm{m}$. Long needles $\mathrm{FeSiAl}_{5}$ sporadically appear at Fe content above $0.7 \mathrm{wt} \%$.

The Excel (LINEST) program was used to calculate the equations expressing the relationship between the composition of the alloy and the mechanical and foundry properties according to the procedure described in $[12,13]$. The individual coefficients of regression equations are given in Table 1. As follows from the values of 
the correlation coefficient $r^{2}$, the correlation between the experimentally determined property values and the values calculated using regression equations can be considered high.

Table 1 Regression equations coefficients and correlation coefficients $r^{2}$.

\begin{tabular}{|l|c|c|c|c|c|c|}
\hline & $\mathbf{S i}$ & $\mathbf{F e}$ & $\mathbf{M n}$ & $\mathbf{M g}$ & constant & $\boldsymbol{r}^{2}$ \\
\hline $\boldsymbol{Y}_{\boldsymbol{z}}$ & 0.480915 & 2.808531 & -1.27922 & 0.13244 & 1.73129 & 0.806 \\
\hline $\boldsymbol{H V 1 0}$ & 2.246563 & 5.198576 & 6.68295 & 42.38626 & 43.46132 & 0.807 \\
\hline $\boldsymbol{R}_{\boldsymbol{m}}$ & 6.909898 & -58.695000 & -15.86840 & -64.17050 & 169.83110 & 0.783 \\
\hline $\boldsymbol{Z}$ & -0.409550 & -3.593790 & -1.09128 & -6.105670 & 11.49576 & 0.735 \\
\hline $\boldsymbol{A}_{\boldsymbol{5}}$ & -0.282040 & -4.532730 & -0.73961 & -6.32229 & 10.72438 & 0.783 \\
\hline
\end{tabular}

The DoE (Design of Experiment) method using Quantum XL software, was used to create a model to predict the mechanical and foundry properties of AISi alloys. DoE allows manipulation of multiple input factors with monitoring of their effect on defined outputs (response) [14,15]. Based on experimental data, was constructed the model, using the DoE historical analysis method. The matrix of the experiment consists of four factors with different levels mentioned above; $\mathrm{Si}(\mathrm{A}), \mathrm{Fe}(\mathrm{B}), \mathrm{Mn}(\mathrm{C})$, and $\mathrm{Mg}(\mathrm{D})$, while five outputs (Y) were monitored: $R_{m}, A_{5}, Z$, hardness $H V 10$ and fluidity $Y_{z}\left(\mathrm{~mm}^{-1}\right)$. Tolerance limits of individual outputs were determined according to standards for Al-Si alloys STN 424332 and STN 424331.

The result of DoE is main effect plots and surface plots, with which we can visually evaluate the significance of the influence of individual chemical elements on the resultant investigated mechanical or foundry property (Figures 1, 2).
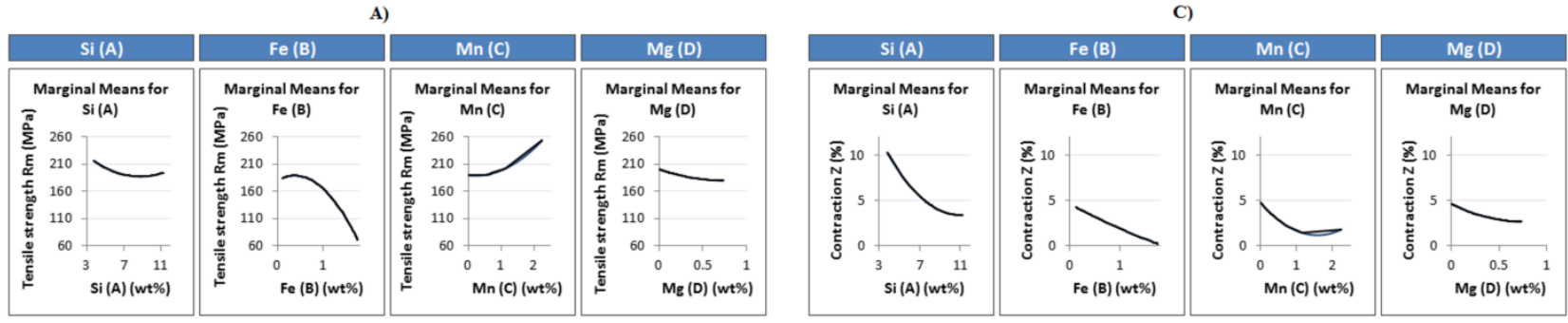

B)
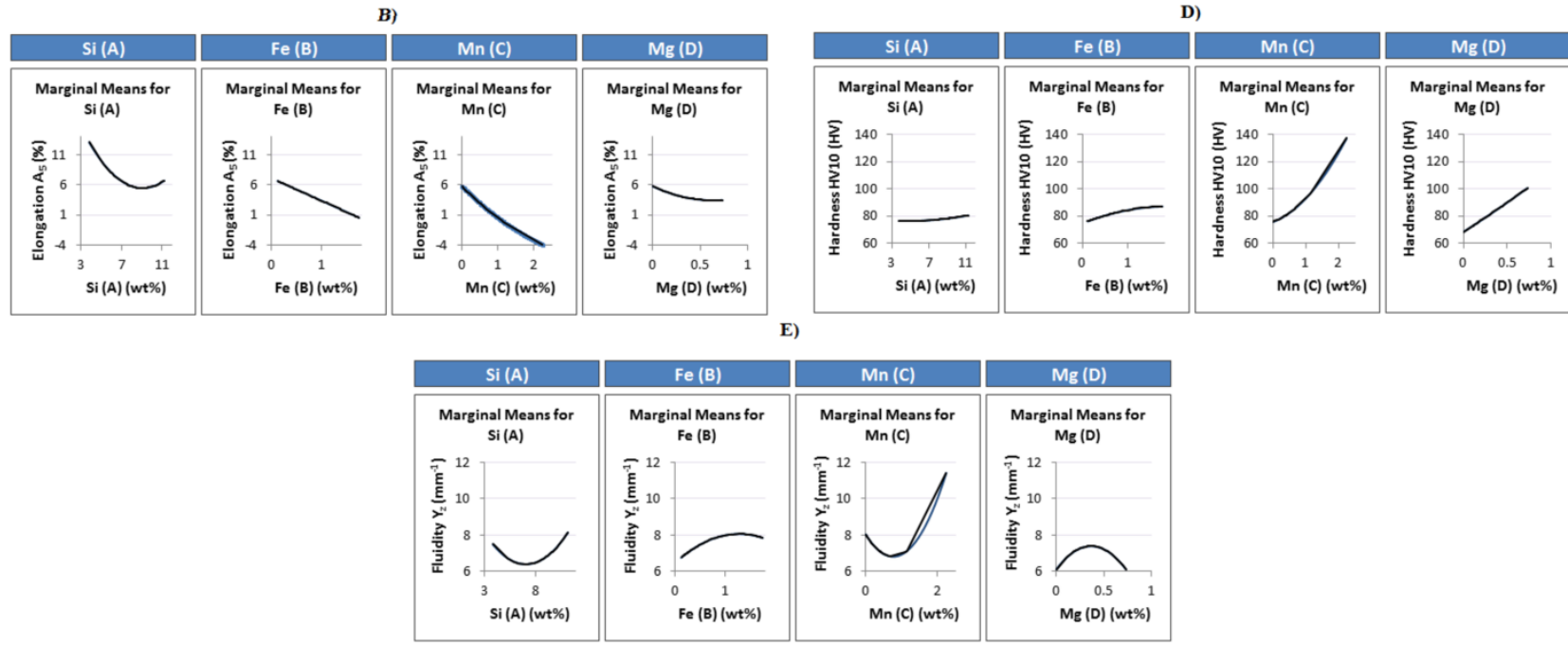

Figure 1 The effect of individual elements on mechanical and foundry properties (main effect response plot) at tensile strength $R m$, contraction $Z$, hardness $H V 10$ and fluidity constant values: $\mathrm{Si}(\mathrm{A})=9.99 ; \mathrm{Fe}(\mathrm{B})=$ 0.38; $\mathrm{Mn}(C)=0.30 ; \mathrm{Mg}(\mathrm{D})=0.25$; at elongation $A_{5}$ constant values: $\mathrm{Si}(\mathrm{A})=9.99 ; \mathrm{Fe}(\mathrm{B})=0.38 ; \mathrm{Mn}(\mathrm{C})=$ $0.01 ; \mathrm{Mg}(\mathrm{D})=0.01$ 
Using regression, we can change the input values of individual chemical elements and monitor changes in the output mechanical and foundry properties. The setting of the optimization goal represents the maximization of the tensile strength $R_{m}$ value, while the optimization constraints must be between 140 and $195 \mathrm{MPa}$. Other optimization constraints were elongation $A_{5}$, which must be between 1 and $2 \%$, and hardness $H V 10$, which must be between 50 and $85 \mathrm{HV}$. Non-standard properties as contraction $Z$ must be greater than $2 \%$ and fluidity must be greater than 7 . In this way, we have defined the optimal content values of individual chemical elements as follows: $9.99 \mathrm{wt} \% \mathrm{Si} ; 0.38 \mathrm{wt} \% \mathrm{Fe} ; 0.3 \mathrm{wt} \% \mathrm{Mn} ; 0.25 \mathrm{wt} \% \mathrm{Mg}$. At this set of factors, the monitored mechanical and foundry properties reach the following values: tensile strength $R_{m}=189 \mathrm{MPa}$; elongation $A_{5}=$ 2.9\%; hardness $H V 10=79 \mathrm{HV}$; contraction $Z=3.5 \%$; fluidity $Y_{z}=7.3$. The coefficient of determination of the created model reaches a high value of $r^{2}>0.8$.

A)

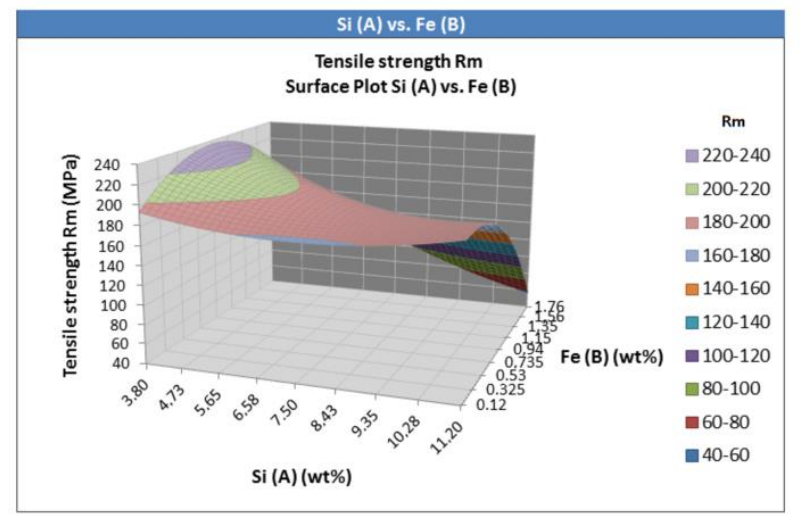

Constant values: $M n(C)=0.30 ; M g(D)=0.25$

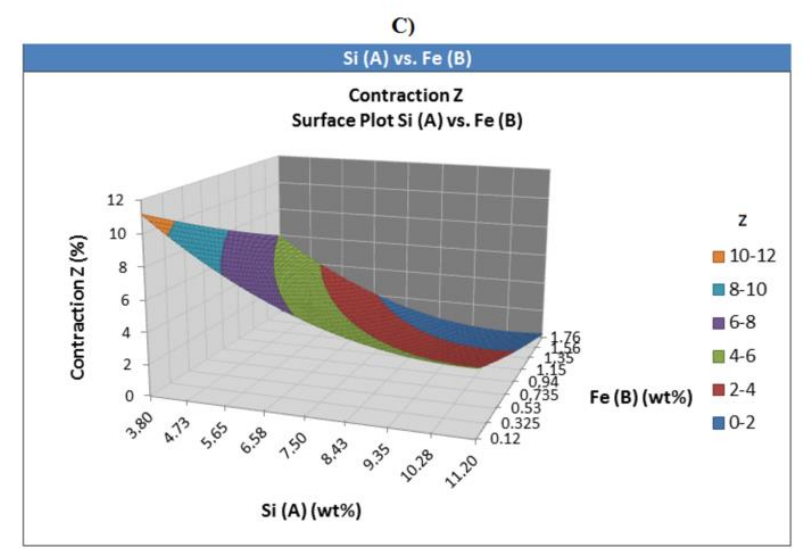

Constant values: $\mathrm{Mn}(C)=0.30 ; \mathrm{Mg}(\mathrm{D})=0.25$

E)

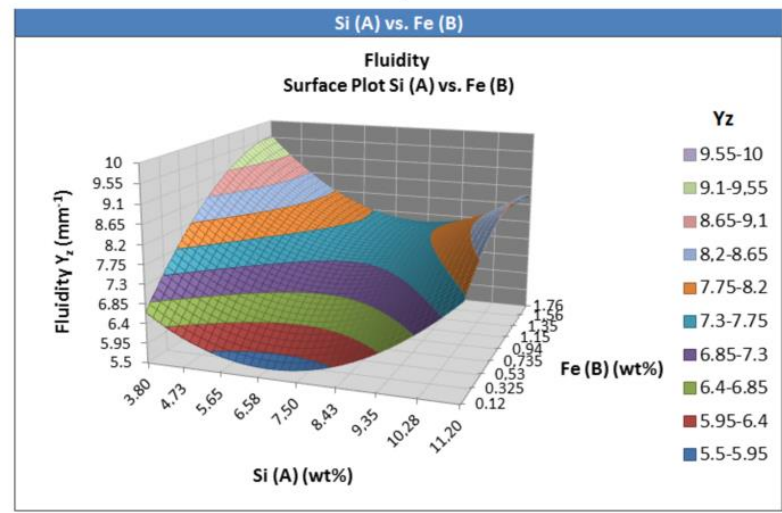

Constant values: $\mathrm{Mn}(C)=0.30 ; \mathrm{Mg}(\mathrm{D})=0.25$
B)

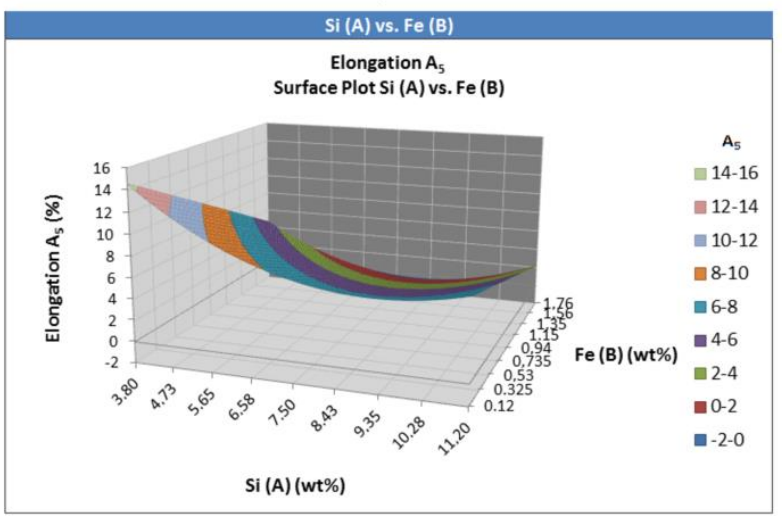

Constant values: $M n(C)=0.01 ; M g(D)=0.01$

D)

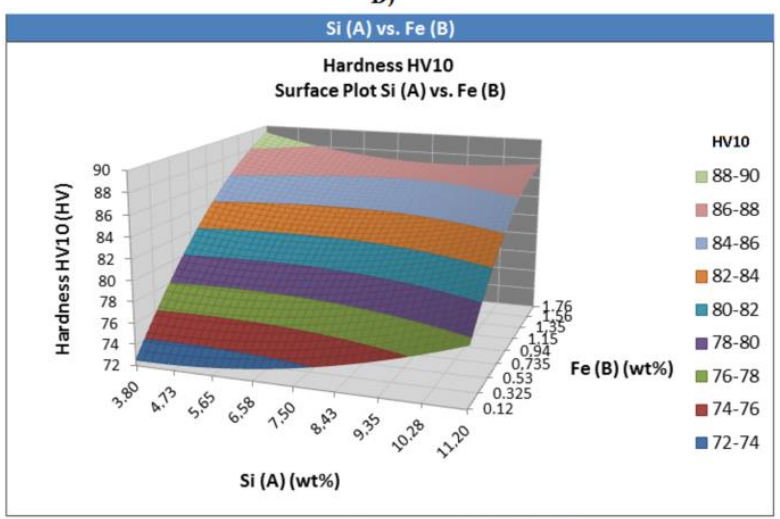

Constant values: $\mathrm{Mn}(C)=0.30 ; \mathrm{Mg}(\mathrm{D})=0.25$

F)

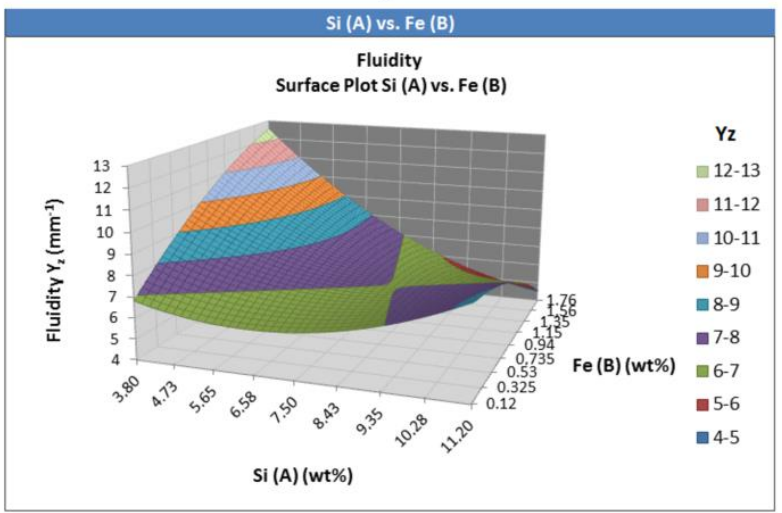

Constant values: $\mathrm{Mn}(\mathrm{C})=0.30 ; \mathrm{Mg}(\mathrm{D})=0.40$

Figure 2 Influence of Si and Fe on mechanical and foundry properties at constant $\mathrm{Mn}$ and $\mathrm{Mg}$ content 
It is clear from the graphs (Figure 1A) that the factor $\mathrm{Fe}(\mathrm{B})$ has the greatest influence on the observed output tensile strength $R_{m}$. Statistical significance is confirmed by the $p$-value of the factor Fe (B) less than $0.05 ; p=$ 0.001.The increase in $\mathrm{Si}, \mathrm{Mg}$ increases $R_{m}$, the opposite tendency seen in the graph may be due to other factors, such as the intense effect of iron, the effect of manganese associated with the formation of "Chinese script", the reaction of magnesium with silicon and iron. Based on these results, the interaction of $\mathrm{Fe}$ and $\mathrm{Si}$ $(\mathrm{AB})$ factors is close to statistical significance, where $p=0.066$ (for more details see Figure 2A). Regarding the graphs (Figure 1B), the greatest influence on the observed output elongation $A_{5}$ has a factor $\mathrm{Si}(\mathrm{A}), p=$ 0.001. In this case, different setting of factors $M n(C)=0.01 \mathrm{wt} \%$ and $M g(D)=0.01 \mathrm{wt} \%$ were taken into account. Close to statistical significance for the observed output contraction $Z$ (Figure 1C) is the factor Si (A), $p=0.082$, and the interaction of factors $\mathrm{Fe}, \mathrm{Mn}$, and $\mathrm{Mg}(\mathrm{BCD})$, where $p=0.062$. The hardness $H V 10$ (Figure 1D) is mostly influenced by the factors $\mathrm{Mn}(\mathrm{C}) p=0.018$, and $\mathrm{Mg}(\mathrm{D}) p=0.007$, while the interaction of these factors (CD), $p=0.043$ is also statistically significant. Regarding the fluidity (Figure 1E), it is likely that the statistical significance of the effect of the composition is to some extent overlaid by other factors related to casting technology (for example, casting rate influenced by the operator, cooling rate of casting, presence of oxide membranes in the melt, etc.). By optimizing in DoE, the Mn content was set to $0.3 \mathrm{wt} \%$ (which is the lower level for STN 424331 and below the lower level for STN 424332 ) and the magnesium content to 0.25 wt\% (which is close to the lower level for standard alloys STN 424331 and 42 4332). True, alloys with such a composition must meet conflicting optimal requirements: it is difficult to meet both the requirements of high strength and hardness on the one hand and high plasticity on the other hand. In addition, it should be noted that fluidity is influenced by a several other factors, as mentioned above. It is expected that as the Si content increases, $R_{m}$ will increase slightly and, conversely, decrease with increasing Fe content. The surface plot modelled by DoE essentially shows the expected trend in Figure 2A. The elongation $A_{5}$ and contraction decrease with increasing $\mathrm{Si}$ and Fe content, the same tendency is seen in Figure 2B for elongation and Figure $\mathbf{2} \mathbf{C}$ for contraction. The model course of the influence of the monitored elements on the contraction is more pronounced. The same course of both plastic properties corresponds to expectations. The hardness increases with increasing $\mathrm{Si}$ and Fe content. In Figure 2D, the effect of Fe corresponds with reality, as does the effect of $\mathrm{Si}$ at low Fe contents. At the higher Fe contents, the influence of $\mathrm{Si}$ is insignificant, whereas it is suppressed by the dominant influence of Fe.

\section{DISCUSSION}

In contrast to the mechanical properties, the effect of $\mathrm{Si}$ and Fe on fluidity is not unambiguous, see Figure 2E. This is due to the above-mentioned influence of other factors, but also due to the mutual, often opposing action of the additives; e.g. fluidity is affected by the ratio of $\mathrm{Fe}$ to $\mathrm{Mn}$ or $\mathrm{Mg}$ due to its tendency to oxidation. As can be seen in Figure $\mathbf{2 F}$, the oxidation products thus formed affect the fluidity. It should be noted, however, that this is a complicated five, or six-element system (if we also take $\mathrm{Sr}$ into account), where the elements that influence the monitored mechanical and foundry properties act complicatedly against each other and their influence is not linear. For instance, Mn to some extent compensates the effect of iron, thereby inhibiting its negative effect on the ultimate strength and plastic properties. At the higher contents, it supports the creation of a "Chinese script", which significantly impairs the fluidity.

There are few publications focused on indicative calculations of mechanical and foundry properties of secondary silumin, not to mention the use of the DoE prediction model. The approach using regression equations were used e.g. Muñoz-lbáñez et al. [16], who used Aluminum Association (AA) and the North American Die Casting Association (NADCA) values as input data. The output is focused on alloys with a silicon content higher than $9.5 \mathrm{wt} \%$. Soundararajan et al. [17] focused on modelling the influence of parameters other than chemical composition - the temperature of the cast alloy and die preheating and another die-casting parameter. They used the Artificial Neural Network (ANN) approach to model the influence of these parameters on the mechanical properties of single alloy castings. Ridgeway et al. [18] used the cellular automaton-finite element analysis (CE-FEA) approach for the prediction of local mechanical properties of castings. The 
microstructure was modelled, including imperfections and related mechanical properties depending on the local cooling rate. Pezda [19] used thermal-voltage-derivative analysis (the ATND method) to predict the mechanical properties of supereutectic silumin, which was related to the crystallization conditions of the casting cooling. From the above mentioned, it is clear that although modelling is used in this field, it deals mainly with casting conditions. The reliability of the regression would certainly be increased by linking the study of the composition impact as presented in this paper as well as in [20] with casting conditions (alloy temperature, casting rate, type, and temperature of the mould), as well as cooling conditions of castings. The investigation of this link represents the further direction in the research.

\section{CONCLUSION}

The benefit of this paper is the calculation of regression equations, which will allow determining the basic mechanical and foundry properties of modified silumin (Al-Si alloy) containing Fe and doped with $\mathrm{Mn}$ and $\mathrm{Mg}$. There is a high level of correlation between the experimental properties and the properties determined using the calculated regression equations.

\section{ACKNOWLEDGEMENTS}

This work was supported by the Slovak Grant Agency for Science VEGA 1/0265/21.

\section{REFERENCES}

[1] TRPČEVSKÁ, J., LAUBERTOVÁ, M. Metal waste and its processing (Kovový odpad a jeho spracovanie). Košice: Technical University of Košice, 2015. In Slovak.

[2] FUTÁŠ P. et al. Non-ferrous metal foundry (Zlievarenstvo neželezných kovov). Košice: Technical University of Košice. 2020. In Slovak.

[3] GRÍGEROVÁ, T., LUKÁČ, I., KOŘENÝ, R. Non-ferrous metal foundry (Zlievarenstvo neželezných kovov). Bratislava/Praha: ALFA/ SNTL, Praha, 1988. In Slovak.

[4] WANG, L., MAKHLOUF, M. APELIAN, D. Aluminium die casting alloys: alloy composition, microstructure, and properties - performance relation ships. International Materials Reviews. 1995, vol. 40, no. 6, pp. 221-238.

[5] SHIVKUMAR, S., WANG, L., APELIAN, D. Molten metal processing of advanced cast aluminium alloys. Journal of Metals. 1991, vol. 1, pp. 26-32.

[6] LECH, Z., SĘK - SAS, G. Continuous process of iron removal from silumins and guidelines for designing of industrial process. Archives of Mechanical Technology and Automatization. 2001, vol. 21, no. 1, pp. 69-77.

[7] PETRÍK, J., HORVATH, M. Their on correctors in Al-Si alloys. Annals of the Faculty of engineering Hunedoara Journal of Engineering. [online]. 2011, vol. 9, no. 3, pp. 401-405. Available from: http://annals.fih.upt.ro/pdffull/2011/ANNALS-2011-3-81.pdf

[8] FUTÁŠ, P., PETRÍK, J., PRIBULOVÁ, A., BARTOŠOVÁ, M. Fluidity test of Al-Si alloy using by computer simulation. Key Engineering Materials. [online]. 2015, vol. 635, pp. 45-50. Available from: https://doi.org/10.4028/www.scientific.net/KEM.635.45.

[9] ISO 6892-1:2018 Metallic materials - Tensile Testing. Part 1. Method of test at room temperature.

[10] ISO 6507-1: 2018 Metallic materials. Vickers hardness test. Part 1. Test method.

[11] ISO 6507-2: 2018 Metallic materials. Vickers hardness test. Part 2. Verification and calibration of testing machines.

[12] McDONALD, J. H.: Handbook of Biological Statistics. [online] 2014 [viewed 2015-05-07]. Available from: http://www.biostathandbook.com/multipleregression.html.

[13] AAKRE, A. Statistical functions and tools in Microsoft Excel. [online] 2004. [viewed 2015-05-18]. Available from: http://trafikk.info/evu tt oslo 2007/litteratur/excel all statistical functions and tools a5.pdf.

[14] Sigma Zone. Quantum XL Software for Microsoft $®$ Excel. [online] 2021[viewed 2021-01-05]., Available from: http://www.sigmazone.com/QuantumXL.htm. 
[15] ASQ. Design of Experiments (DoE) Tutorial. [online]. 2021 [viewed 2021-02-22]. Retrieved from Design of Experiments: Available from: http://asq.org/learn-about-quality/data-collection-analysis-tools/overview/design-ofexperiments-tutorial.html.

[16] MUÑOZ-IBÁÑEZ, C. A. et al. Design and application of a quantitative forecast model for determination of the properties of aluminum alloys used in die casting. International Journal of Metal Casting. [online]. 2019, vol. 13, no. 1, pp. 98-111. Available from: https://doi.org/10.1007/s40962-018-0231-6.

[17] SOUNDARARAJAN, R. at al. Modeling and analysis of mechanical properties of aluminium alloy (A413) processed through squeeze casting route using artificial neural network model and statistical technique. Advances in Materials Science and Engineering. [online]. 2015, Article ID 714762, p. 16. Available from: http://dx.doi.org/10.1155/2015/714762.

[18] RIDGEWAY, C. D. at al. Prediction of location specific mechanical properties of aluminum casting using a new CA-FEA (cellular automaton-finite element analysis) approach. Materials and Design. [online]. 2020, vol. 194, Article 108929. Available from: https://doi.org/10.1016/j.matdes.2020.108929.

[19] PEZDA, J. Prediction of mechanical properties of $\mathrm{AISi}_{13} \mathrm{Cu}_{2} \mathrm{Fe}$ alloy using the ATND methods. Materials Research. [online]. 2016; vol. 19, no1, pp. 252-257. Available from: http://dx.doi.org/10.1590/1980-5373-MR2015-0099. 